\title{
Spekulacje głównym powodem wzrostu wartości nieruchomości
}

\section{Speculations as the main reason behind real estate price increase}

\section{Streszczenie}

Najbardziej interesujący dla osoby badającej rynek nieruchomości jest wpływ pieniądza na przemianę dzielnic położonych w miejscach mniej eksponowanych - niż centrum miasta. Jaki jest powód metamorfozy takich zaniedbanych dzielnic? Obserwacje prowadzone w części Nowego Jorku, dzielnicy Red Hook, pomogą zrozumieć mechanizmy rządzące wyborem lokalizacji do zamieszkania. W Red Hook w ciągu ostatnich 8 lat apartamenty zdrożały kilkakrotnie. Do rozwoju miasta potrzebna jest: nadwyżka pieniędzy, które można zainwestować w przedsięwzięcie przynoszące zysk - to zjawisko kumulacji charakteru miejsca i zadziałania „zapalnika” cenowego. Dlatego teza mówiąca, że spekulacje są głównym powodem wzrostu wartości nieruchomości, wydaje się zasadna i możliwa do udowodnienia.

Słowa kluczowe: centrum miasta, zaniedbana dzielnica, wzrost cen, nieruchomości, potencjał miejsca, atrakcyjność miejsca

\begin{abstract}
The most interesting for a real estate market researcher is influence of money on transformation of districts located outside of the city center. What is the reason of the transformation of these neglecteddistricts? Observations made in the NY area of Red Hook will help to understand the mechanisms behind the choice of location for living. During last 8 years, prices of apartments in Red Hook have risen several times. Development of city needs excess money that could be invested into the project that generate profit. This is the phenomenon of accumulating attractiveness of the place together with activation of the price ,igniter". Therefore, the theory that speculation is the main reason for the increase in property value seems reasonable and possible to prove.
\end{abstract}

Keywords: City Centre, neglected district, price increase, real estate, potential of the area, area attractiveness 


\section{WSTĘP}

Doświadczenia zdobywane w wielkich aglomeracjach mogą być materiałem badawczym dla osób zajmujących się projektowaniem i rynkiem nieruchomości. Na podstawie materiału badawczego będzie można również stawiać prognozy i planować w nieporównywalnie mniejszej skali małych miast i gmin wiejskich. Najważniejsze jest określenie jakie zdarzenia i uwarunkowania powodują wzrost wartości terenów budowlanych i budynków. Cena nieruchomości jest swoistego rodzaju soczewką skupiającą wszystkie składowe wpływające na ocenę miejsca zamieszkania. Zrozumienie mechanizmu inwestycyjnego powinno pomóc w prawidłowych decyzjach podejmowanych w planowaniu przestrzennym .

\section{POTENCJAŁ DZIELNICY}

Nowy Jork jest ogniwem globalnej gospodarki. Ten niepodważalny fakt ściśle wiąże się z dziedzinami nas interesującymi; architekturą i rynkiem nieruchomości ${ }^{1}$. Obserwując zmieniający się krajobraz miasta, trzeba zadać sobie pytanie o powód przemiany „zapomnianych dzielnic". Najciekawszą relacją dla osoby zawodowo zajmującej się projektowaniem i poszukującej prognoz dla rynku nieruchomości jest zrozumienie mechanizmu powodującego wzrost ceny nieruchomości co najczęściej jest równoważne z przemianą dzielnic peryferyjnych (np. położonych w miejscach mniej dostępnych, na przeciwnym brzegu rzeki niż centrum miasta...).

Jako przykład modelowy wybrano fragment nabrzeżnej dzielnicy Brooklinu, tereny Red Hook. Podczas wyjazdu studialnego w listopadzie 2016 r. przeprowadzono obserwację połączoną ze zbieraniem danych dotyczących cen na rynku nieruchomości. Red Hook to bardzo charakterystyczne miejsce, w którym w czasie ostatnich 8 lat (okres 2007-2015, z którego pochodzą dane) wartość działek wzrosła do poziomu cen porównywalnych nieruchomości w najbardziej znanej i prestiżowej dzielnicy Nowego Jorku - Manhattanie. To bardzo interesujące zjawisko i doświadczenie, które pomoże zrozumieć mechanizmy świata inwestycji. Ciekawy jest fakt, że wszystko stało się bez ingerencji planistycznej. Brak widocznej dla człowieka z zewnątrz ingerencji administracji publicznej. Nieruchomości były wykupywane przez inwestorów, a następnie burzono budynki lub przebudowano na apartamenty. Nieruchomość, która dotąd była warta kilkaset tysięcy, nagle zyskała wartość kilku milionów dolarów.

Szukając przyczyn gwałtownego wzrostu cen nieruchomości w celu usystematyzowania wiedzy, należy rozróżnić dwa rodzaje przyczyn: pośrednie- to znaczy takie, które mogą stanowić o wzroście wartości, ale które występują w wielu miejscach w których niekoniecznie ceny rosną i bezpośrednie - to znaczy takie, które są zapalnikiem inicjującym „wybuch” cen.

Końcowa analiza polega na porównaniu wzrostu cen z czynnikami należącymi do pierwszej i drugiej grupy i powinna zaowocować wynikiem miarodajnym dla badania. Trzeba 
w tym miejscu nadmienić, że ceny nieruchomości zostały przyjęte jako element porównawczy, odzwierciedlający atrakcyjność miejsca zamieszkania. Jest to najłatwiejsza metoda porównawcza, ponieważ, jak już nadmieniłem, cena nieruchomości jest swoistego rodzaju soczewką skupiającą wszystkie składowe, wpływające na ocenę miejsca zamieszkania.

W USA rynek nieruchomości posiada instrumenty pomagające ocenić inwestycję praktycznie w każdym aspekcie. Istnieją powszechnie dostępne bazy danych, które służą zarówno profesjonalistom, jak i potencjalnym kupującym.

Takimi sprawdzonymi instrumentami są: www.zillow.com - strona będąca bazą ofert, oraz www.neighborhoodscout.com - strona z danymi statystycznymi zebranymi przez Census Bureau. Census jest organizacją rządową zbierającą dane statystyczne na temat ludzi i gospodarki kraju (www.census.gov). To jedyny przejaw na badanym terenie współdziałania biznesu i administracji.

Na podstawie danych opublikowanych przez Neighborhoodscout, charakterystyka dzielnicy Red Hook jest następująca:

\section{CENY NIERUCHOMOŚCI I DANE OGÓLNE}

W Red Hook średnia cena nieruchomości wynosi 1061967 dol., jest wyższa niż cena w 93,8\% lokalizacji aglomeracji Nowego Jorku i 97,9\% cen nieruchomości na terenie USA.

Średnia cena wynajmu w Red Hook wynosi obecnie 2016 dol., a średni koszt wynajmu w tej dzielnicy jest wyższy niż 77,6\% lokalizacji aglomeracji Nowego Jorku.

Red Hook jest zaliczana do podmiejskich dzielnic (na podstawie gęstości zaludnienia) i zlokalizowana jest nad oceanem. Przeważają tam małe (do dwóch sypialni) i średnie (trzy lub cztery sypialnie) domy, w zabudowie zwartej wielorodzinnej, ale również znajdują się tu wysokie budynki mieszkalne (wieżowce). Większość domów jest zamieszkana.

Red Hook posiada 12,5\% wskaźnik pustostanów, który jest znacznie powyżej średniej w porównaniu do innych obszarów w Nowym Jorku jak również w innych miastach amerykańskich. Jest to wskaźnik wyższy od 66,2\% porównywalnych dzielnic na terenie USA. Większość nieruchomości przedstawionych jako oferty najmu jest wolna przez dłużej niż 1 rok, co może sygnalizować słaby popyt na nieruchomości w tej dzielnicy lub dużą ilości nowych mieszkań, które nie zostały jeszcze sprzedane lub wynajęte. Powyższe stwierdzenie pokazuje trudność interpretacji danych statystycznych, gdyż czym innym może być nowo wybudowany „pustostan”, a czym innym jest porzucony budynek. 


\section{UNIKALNE CECHY OKOLICY (NP. STYL ARCHITEKTONICZNY BUDYNKÓW, TOPOGRAFIA TERENU I SAZSIEDZTWO)}

Pierwszorzędną cechą, która decyduje o zainteresowaniu się miejscem dla osiedlenia, jest wygląd sąsiedztwa i charakter dzielnicy. Oznacza to najczęściej styl architektoniczny (wiążący się z datą powstawania budynków) oraz cechy okolicy wiążące się w USA (ale nie tylko) z pochodzeniem zasiedlających je mieszkańców.

Red Hook jest nadmorską dzielnicą, która właśnie z tego powodu ma duży potencjał rekreacyjny. Część wybrzeża przy mniej zamożnych i gęściej zaludnionych terenach ma charakter przemysłowy i jest trudniejsza do udostępnienia dla potrzeb rekreacji. Żeglarskie sąsiedztwo i morska atmosfera cieszą zmysły na rożny sposoby; wizualnie i dźwiękowo.

34,9\% nieruchomości w Red Hook to małe budynki wielorodzinne z 2, 3 lub 4 mieszkaniami. Taka struktura jest unikalna w skali całego USA, to większy udział małych budynków wielorodzinnych niż w 95,3\% porównywalnych dzielnic w USA. Zaletą takiej struktury substancji mieszkaniowej jest łatwość jej adaptacji na apartamenty. Interesujące dla nabywców mieszkań są małe obiekty gastronomiczne wyróżniające tę dzielnicę.

Red Hook charakteryzuje się tym, że przez dominację małych budynków wielorodzinnych zyskuje się tutaj możliwości dobrego sąsiedztwa. Kolejnym atutem jest atmosfera historyczna, ponieważ aż 68,7\% budynków powstało nie później niż w 1939 roku, a niektóre znacznie wcześniej. Jak podają statystyki, okolica ta ma większą koncentrację zabytkowych rezydencji niż 97,7\% porównywanych dzielnic w USA. Dlatego Red Hook jest wyjątkową częścią Nowego Jorku. W dzielnicy znajduje się również wiele atrakcyjnych budynków zbudowanych po $2000 \mathrm{r}$.

\section{TRANSPORT}

Codzienne używanie rowerów w tej dzielnicy jest bardzo powszechne. Stwierdzono, że 14,7\% mieszkańców dojeżdża na rowerze do pracy. Dzielnica ma więcej dojeżdżających rowerami niż 99,8\% lokalizacji w USA. Istnieje dogodne połączenie komunikacją zbiorową. Badania NeighborhoodScout wykazały, że 41,6\% osób dojeżdża każdego dnia do pracy pociągiem. To więcej niż w 98,2\% dzielnic miast Ameryki. Na analizowanym obszarze aż $14,1 \%$ mieszkańców chodzi do pracy na piechotę, jest to więcej niż w 96,2\% dzielnic miast amerykańskich.

46,7\% pracujących mieszkańców poświęca na dojazdy od 45 minut do jednej godziny w jedną stronę, to więcej niż poświęca na dojazd większość pracujących w USA. W Red Hook jedynie $15,6 \%$ osób dojeżdża do pracy samochodem. 


\section{POCHODZENIE I SKŁAD NARODOWOŚCIOWY}

W Red Hook dominują następujące grupy etniczne: pochodzenie z Puerto Rico deklaruje 14,8\%, irlandzkie 9,6\%, włoskie 9,4\%, meksykańskie 8,3\% i niemieckie 6,9\%.

19,9\% mieszkańców tej dzielnicy urodziło się w innym kraju. Najczęściej używanym językiem w domu jest angielski, który używa 63,9\% rodzin. Innymi ważnymi językami są: hiszpański i język niemiecki (którego używa w domu aż 3,6\% mieszkańców, jest to więcej niż w 99,5\% porównywalnych terenów w USA).

\section{SAMOCHÓD}

Dzielnica jest bardzo nietypowa, jeśli chodzi o posiadanie samochodu. Aż w 39,8\% gospodarstw domowych w tej okolicy nie posiada samochodu. Jest to więcej niż stwierdzono w 97,9\% dzielnic miast amerykańskich.

\section{DOCHÓD}

Dochody mieszkańców są w grupie średnio-wysokich. Dzielnica ma wyższy dochód niż $77,2 \%$ dzielnic miast w USA. Ale aż 22,1\% dzieci żyje poniżej „federalnego progu ubóstwa”. Jest to wyższy wskaźnik biedy niż w 60,7\% dzielnic miast amerykańskich. Oznacza to, że istnieje duże zróżnicowanie dochodów wśród mieszkańców. Zjawisko to związane jest ze zróżnicowanym pochodzeniem i wykształceniem.

\section{WYKONYWANE ZAWODY}

48,5\% pracujących zatrudniona jest w zawodach wymagających wysokich kwalifikacji (profesjonaliści i zarządzający). Drugą najważniejszą grupą zawodową stanowiącą 26,6\% populacji w tej okolicy są pracownicy sektora usług. Począwszy od dobrze zarabiających fachowców do pracowników restauracji fast food. Pozostałe grupy to: robotnicy $(13,0 \%)$ oraz niżsi pracownicy biurowi, wykonujący mniej odpowiedzialne zadania (12,0\%).

Ważnym elementem wpływającym na chęć zamieszkania w konkretnej okolicy jest bezpieczeństwo, co wiąże się z niską liczbą przestępstw. Należy w tym miejscu zaznaczyć, iż wzrost cen nieruchomości nie zawsze kojarzy się z powszechnie utartymi opiniami na temat lokalizacji. Opisywany rejon Red Hook jest częścią zachodniego Brooklyn, który ma złą opinię w aglomeracji nowego Jorku. Zbliżoną do opinii o dzielnicach Bronx i Harlem². 
Powodem różnicy pomiędzy faktyczny stanem i stereotypem jest „bezwładność plotki”, co oznacza, że zmiany dzielnicy są szybsze od zmiany opinii na jej temat. Kupujący korzystają z wiarygodnych źródeł, jakimi są statystyki przestępstw. Czyli obiegowe opinie nie wpływają na decyzję o zamieszkaniu. Powyższe informacje można znaleźć u pośredników i w specjalistycznych serwisach internetowych. Ciekawym materiałem opisującym problem przestępstw, jest opracowanie sporządzone przez NeighborhoodScout, na które składają się: dane gromadzone przez Census (Census Bureau jest organizacją rządową zbierającą dane statystyczne), dla rejonów zamieszkałych przez więcej niż 800 osób oraz dane FBI dotyczące najgroźniejszych przestępstw, takich jak morderstwa, gwałty, napady z bronią w ręku, czy rozboje. W powyższym opracowaniu, we wnioskach, zwrócono uwagę, iż centra miast gdzie koncentruje się handel, turystyka i gdzie trafia najwięcej inwestycji są zwykle bardziej bezpieczne, niż obrzeża, czy bliskie przedmieścia. Historycznie, największa przestępczość utrzymywała się w dzielnicach z budynkami wielorodzinnymi (wyższa zabudowa). Współczesne dane mówią o zmianie sytuacji. Najbardziej niebezpiecznymi są rejony z niską zabudową, najczęściej domami jednorodzinnymi. Zwrócono uwagę na fakt, że są to również miejsca, gdzie znajduje się najwięcej pustostanów. Dane mówią że Nowy Jork jest miastem stosunkowo bezpiecznym, a liczba przestępstw jest porównywalna do 10-krotnie mniejszego Detroit - najniebezpieczniejszego miasta w USA. W opracowaniu stwierdzono, że wielkie metropolie są względnie bezpieczne.

Charakterystyka historyczna dzielnicy Red Hook wskazuje na jej gorsze „pochodzenie”, ponieważ, był to zwykły port na peryferiach metropolii, miejsce obarczone wszystkimi przywarami związanymi z niedogodnościami dzielnicy przemysłowej i z bagażem struktury społecznej właściwej takim miejscom. Konsekwencją historii dzielnicy jest istniejąca substancja budowlana, stare budynki takie jak: magazyny, małe fabryki i niepozorne budynki mieszkalne.

Ten niewyszukany wydawałoby się potencjał okazał się zaletą. Duża liczba małych budynków, łatwych i tanich do przebudowy i adaptacji lub wyburzenia, jak również wiele miejsc pustych jest ogromną wartością. Połączenie tych zasobów oraz interesującej lokalizacji, której unikalne cechy, takie jak styl architektoniczny budynków, topografia terenu i sąsiedztwo - nadmorska dzielnica z dużym potencjałem rekreacyjnym (opisałem w p. 2 powyżej), jest warunkiem wystarczającym do stworzenia podstaw do inwestowania w nieruchomości. Jest też podstawą sukcesu rozumianego jako rozkwit dzielnicy. Nie mniej ważny jest czynnik ludzki, przez co rozumiem istnienie potencjalnej grupy kupców chętnych do spekulacji nieruchomościami. Takie zjawisko można nazwać-zapalnikiem inicjującym „wybuch” cen.

\section{OBSERWACJA RUCHU BUDOWLANEGO}

Istnienie „zapalnika” zostało sprawdzone przez obserwację wzrostu cen i ruchu budowlanego. Widoczne w krajobrazie dzielnicy nowe budynki były pierwszą przesłanką, sygnalizująca przemiany, tę która wzbudziła zainteresowanie dzielnicą. Na przedstawionych wykresach 
można porównać „płaskie” ceny przeważające w Nowym Jorku ze „stromą” zwyżką w analizowanej lokalizacji. Porównanie cen na konkretnych przykładach kształtuje się następująco: 1. Zabudowa szeregowa przy King St. autorstwa AA studio, które jest firmą deweloperskoprojektową. Architekci zaprojektowali domy 3 kondygnacyjne na terenie gdzie wcześniej wyburzono zabudowę istniejącą. Powstały niskie budynki nawiązujące do wysokości domów dzielnicy. Nowe domy budowane były prostymi, tanimi, ogólnoznanymi w Ameryce technikami, które gwarantują przy stosunkowo małych nakładach finansowych duży zysk. Każdy z domów ma indywidualną elewację (por. il. 1-3).

2. Dawne i obecne zagospodarowanie działki przy Van Brunt St. 267 jest sztandarowym przykładem zmian Red Hook. Zdjęcia i wykres obrazują przemiany (il. 4-6). Jest to bardzo dobry przykład na dostosowanie wielkości projektowanego budynku do otoczenia.

3. Nieruchomość przy Van Brunt St. 242 to przykład domów jednorodzinnych które zyskały nową tożsamość po zmianie stylu architektonicznego. Stare budynki przebudowano w duchu dobrze pojętej nowoczesności. Świadczy to o bardzo specyficznym jak na warunki amerykańskie profilu kupujących nieruchomości w tej dzielnicy. Sąsiadujące ze sobą elewacje budynku modernistycznego i klasycznego pokazują, jak czułe musi być oko dewelopera i jak powinien być elastyczny przy wyborze projektu (il. 7, 8).

4. Adaptacji został poddany budynek wielorodzinny 4 kondygnacyjny quasi-szeregowy, wokół którego teren zajmują bardzo modne w Nowym Jorki (również na Manhattanie) warzywniki w „donicach”. Bardzo modne jest uprawianie własnej marchewki. To kolejny symptom, wskazujący na specyficzny typ mieszkańca dzielnic w których następuje skok cen nieruchomości (il. 9-11).

5. Kolejnym przykładem jest nowy budynek mieszkalny przy Van Brunt St. 346. To exemplum ilustrowane zdjęciem może nasunąć stwierdzenie o braku zainteresowania władz przemianami dzielnicy (il. 12-13). Takie radykalne stwierdzenie można wysunąć na podstawie obrazu jaki rysuje się na wspomnianej ilustracji. Plątanina napowietrznych kabli pokazuje że miasto nie dokłada nawet dolara do przeobrażeń w dzielnicy, a jej nowe oblicze to zasługa prywatnych inwestorów.

6. Wzrost cen to również podrożenie czynszów. W obszarze badań przykładem może być znajdujący się budynek wielorodzinny z mieszkaniami na wynajem przy Columbia St. 213, w którym czynsz dwupokojowe mieszkanie o pow. 125 $\mathrm{m}^{2}$ wynosi 4246 dol./miesiąc.

7. Budynek wielorodzinny przy Columbia 65 to typowa przebudowa w omawianym obszarze (il. 15, 16).

8. Apartamenty przy Furman St. (il. 17,18 ) to nieruchomości porównywalne z terenem po drugiej stronie East River na Manhattanie. Ceny apartamentów to od 3,5 do $6 \mathrm{mln}$ dol. za dwupokojowy apartament. Taka wartość świadczy bezsprzecznie o budowanym prestiżu miejsca. Ta lokalizacja nie leży w omawianym w tym artykule terenie, ale została przytoczona, aby uzmysłowić, jak obszar prestiżu powoli rozrasta się poza centrum historycznie utożsamiane z bogactwem i „dobrymi dzielnicami”. Działka ta znajduje się bliżej mostu 
Brooklińskiego (symbolu Nowego Jorku od 134 lat) niż Red Hook. To znakomite sąsiedztwo ma wpływ na zainteresowanie władz miasta terenami nabrzeży. Tutaj odmiennie niż w innych częściach Brooklynu (casus Red Hook) miasto przebudowuje nabrzeża, które podobnie jak w Chicago są najbardziej atrakcyjnymi terenami rekreacyjnymi i sportowymi w mieście. Obok terenów spacerowych znajdują się liczne boiska, w tym: piłkarskie oraz do innych gier i pola treningowe do golfa. Obiekty sportowe mieszczą się na sztucznej wyspie wyrwanej morzu. Świadczą o procesie nobilitacji dzielnicy.

9. Apartamenty przy Imlay St.160 (il. 19, 20) to przebudowa dawnych magazynów na 52 luksusowe apartamenty z widokiem na Manhattan.

Proces gentryfikacji w Red Hook jest bezsprzeczny³. Pojawiający się w dawnych „złych” dzielnicach nowi mieszkańcy i ich nowy sposób życia zmieniają oblicze miast. Ludzie szukający „modnych miejscówek” wprowadzają nowe obyczaje charakterystyczne dla ludzi zamożnych. Brooklyn jest miejscem kultowym dla literatury i filmu, legenda Brooklynu dobrze się sprzedaje i rośnie popyt na „trendy” dzielnicę Red Hook.

Pojawiające się przykłady są jedynie czubkiem góry lodowej. Obserwując dane wartości sprzedaży nieruchomości (na platformie Zillow), można stwierdzić, że wszystkie działki w dzielnicy odnotowały wzrost wartości.

\section{PODSUMOWANIE}

Po analizie wszystkich aspektów na przykładzie Red Hook stwierdzono, że do rozwoju miasta potrzebna jest przede wszystkim przedsiębiorczość - biznes równoważny z nadwyżką pieniędzy, które można zainwestować w przedsięwzięcie przynoszące zysk. W przedstawionym obszarze tak się stało. Potwierdzeniem tezy jest opisane zjawisko - kilkudziesięciu deweloperów przed kilkunastu laty kupiło tanio działki, które obecnie sprzedają drogo. Stało się to w wyniku implozji charakteru miejsca i zadziałania „zapalnika” cenowego. Można zauważyć, że wśród wymienionych cech/faktów brak jest pomysłów ojców miasta na urządzenia życia dzielnicy. Dlatego teza mówiąca, że spekulacje są głównym powodem wzrostu wartości nieruchomości wydaje się zasadna i możliwa do udowodnienia. Przytoczony amerykański przykład jest zwycięstwem kwalifikacji merytorycznych i psychicznych inwestorów. Samodzielne tworzenie dobrobytu, który jest warunkiem wolności, jest umiejętnością niezbędną i najważniejszą dla istnienia cywilizacji i człowieka. 


\section{Zestimate -}

- This home

-.. New York
1 year 5 years 10 years

Forecast $_{\$ 4.0 \mathrm{~m}}$

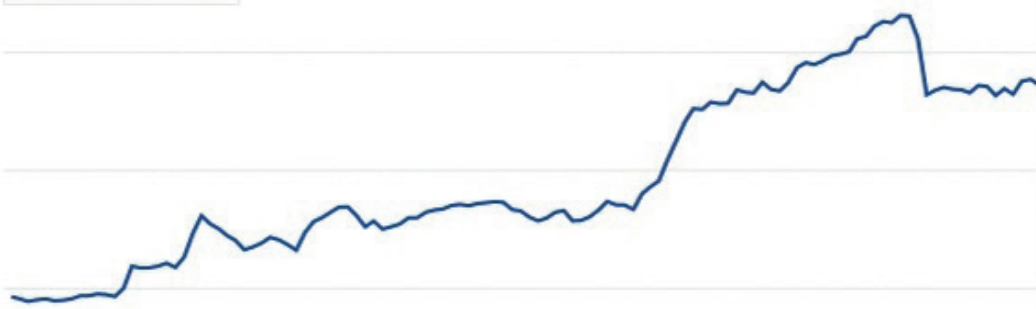

$\$ 1.0 \mathrm{~m}$

$\$ 0$

$\$ 3.0 \mathrm{~m}$

? $\$ 2.0 \mathrm{~m}$

Dec 2007

Dec 2009

Dec 2011

Dec 2013

Dec 2015

II. 1. Wzrost cen nieruchomości przy King\&Sullivan Street (źródło: www.zillow.com) III. 1. Rise in property prices at King\&Sullivan St.

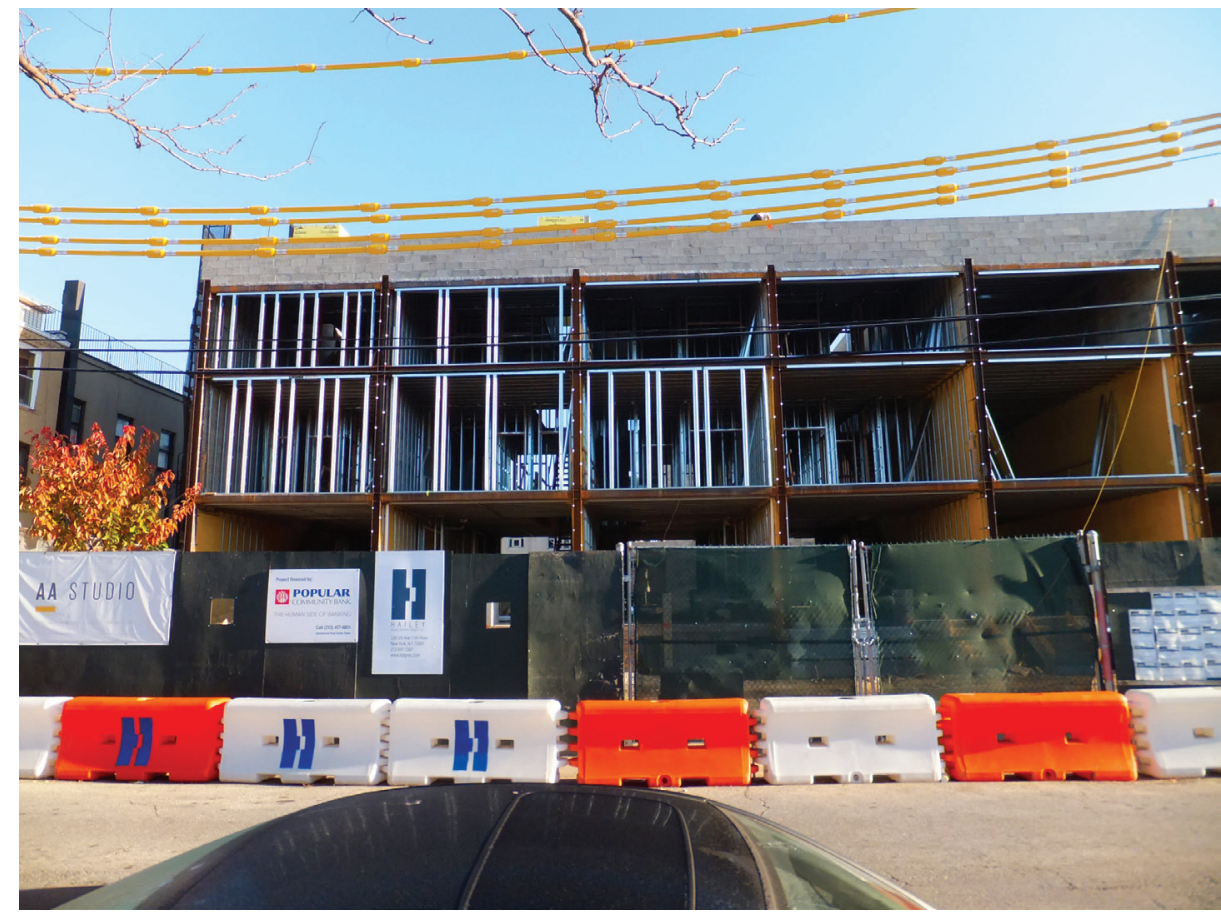

II. 2. Budynki mieszkalne, metody budowania (fot. J. Huebner) III. 2. Residential buildings, ways of building 


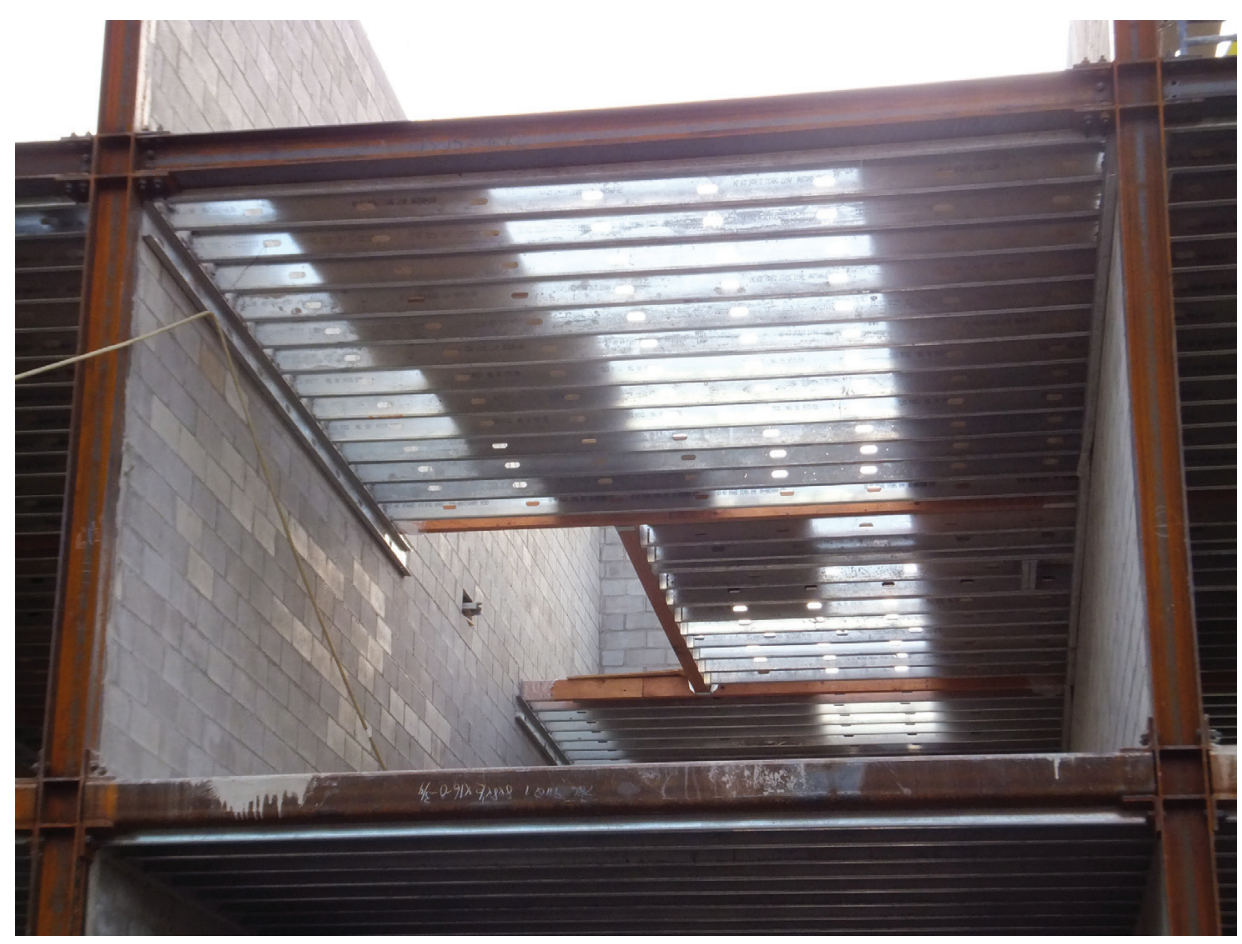

II. 3. Budynki mieszkalne, metody budowania (fot. J. Huebner) III. 3. Residential buildings, ways of building

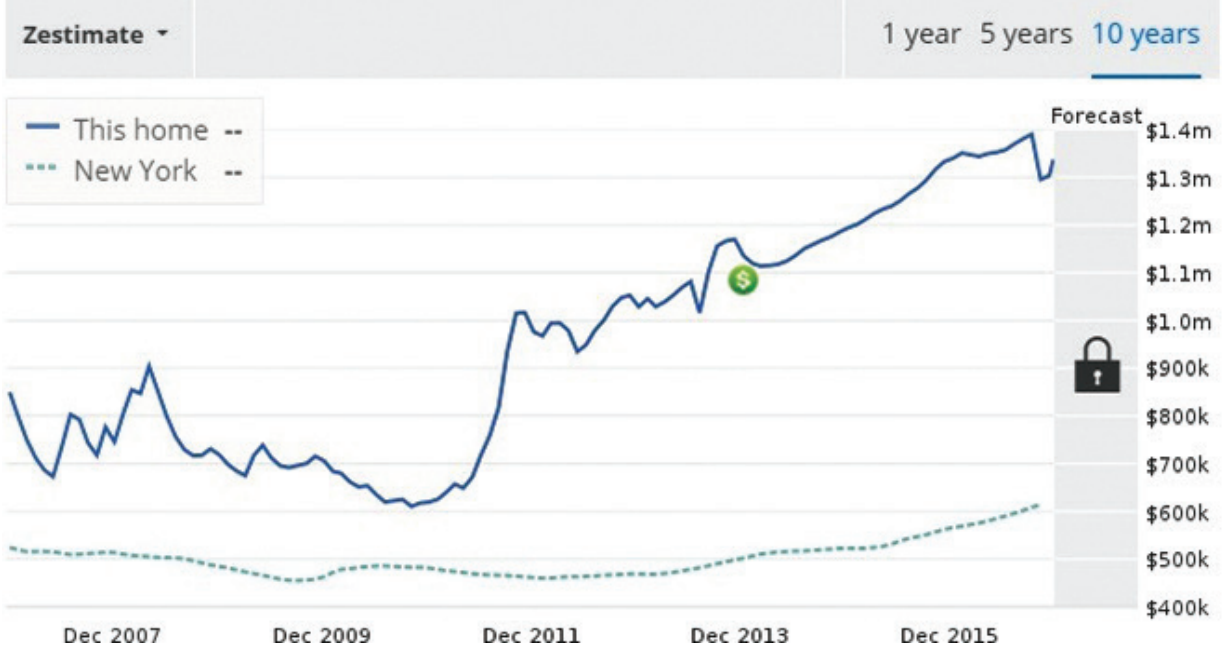

II. 4. Wzrost cen nieruchomości przy Van Brunt Street (źródło: www.zillow.com)

III. 4. Rise in property prices at Van Brunt St. 


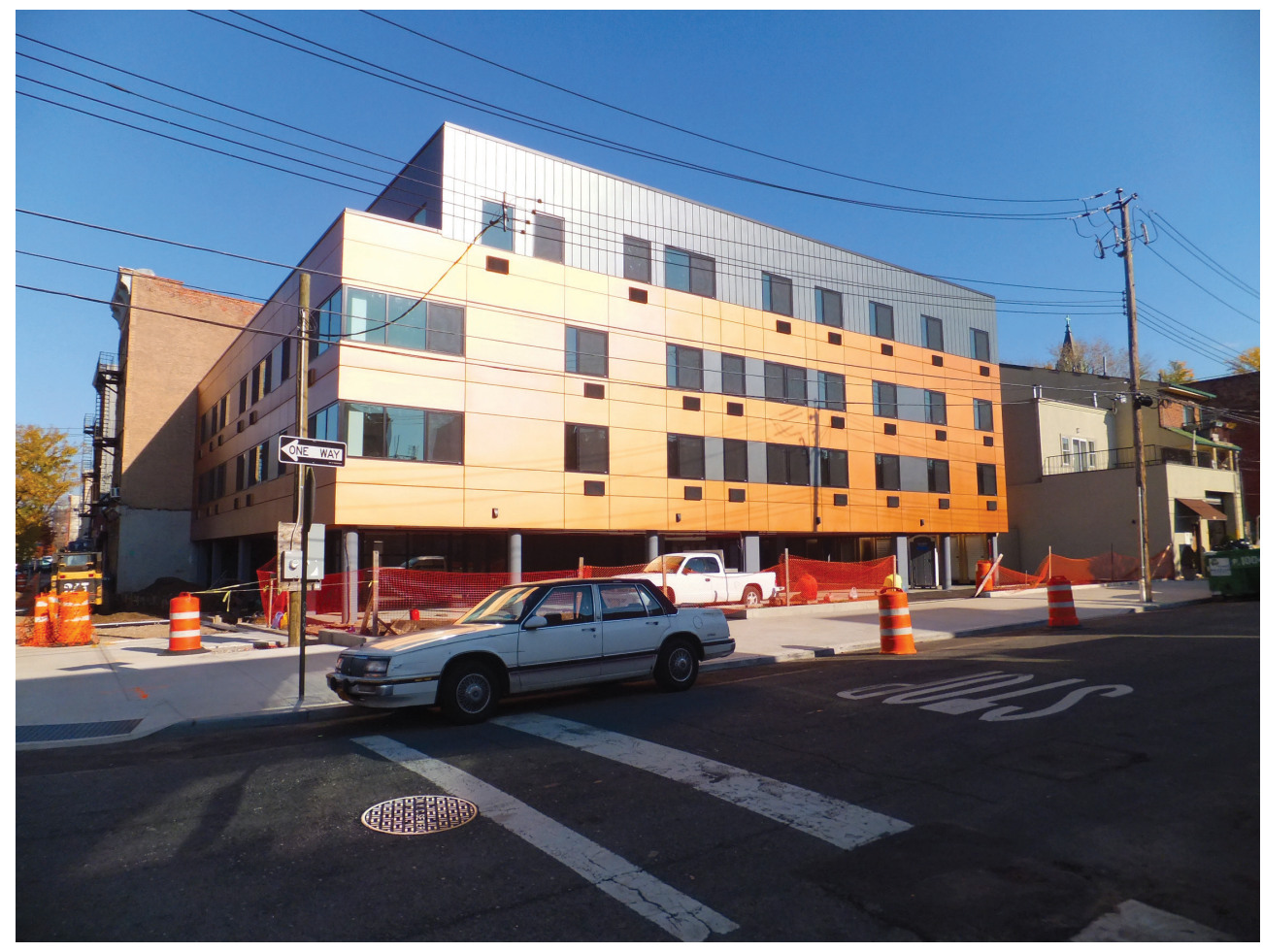

II. 5. Budynki mieszkalne wielorodzinne (fot. J. Huebner) III. 5. Multifamily residential buildings

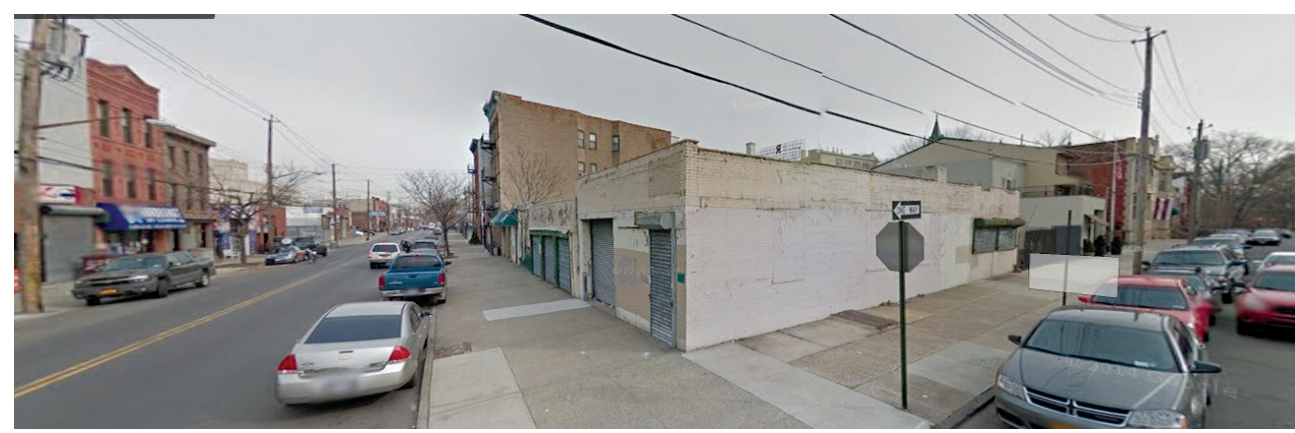

II. 6. Dawna zabudowa działki (źródło: www.google.com) III. 6. Old building site 


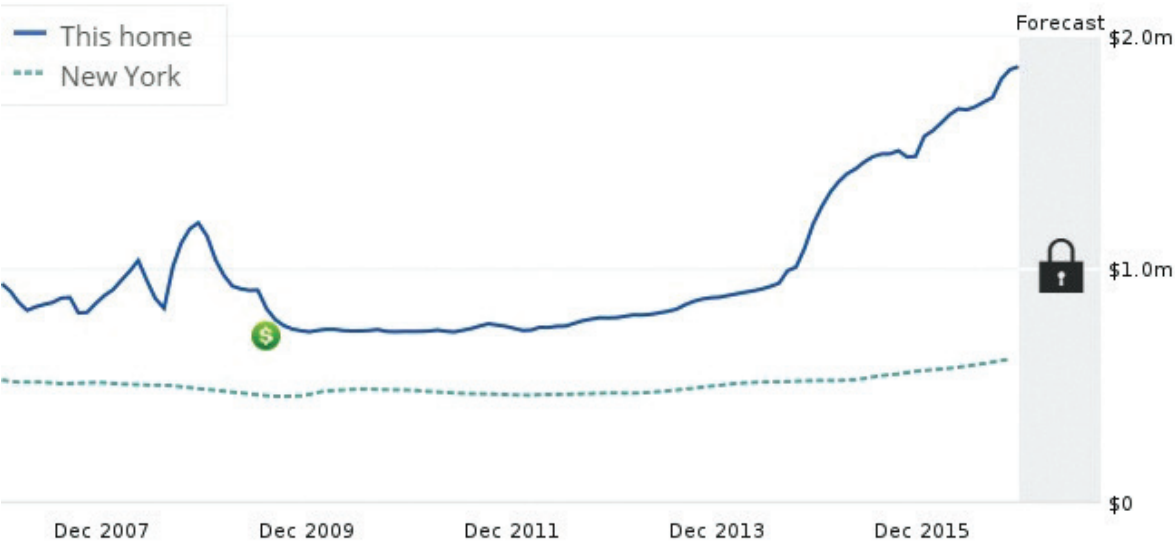

II. 7. Wzrost cen nieruchomości przy Van Brunt Street (źródło: www.zillow.com)

III. 7. Rise in property prices at Van Brunt St.

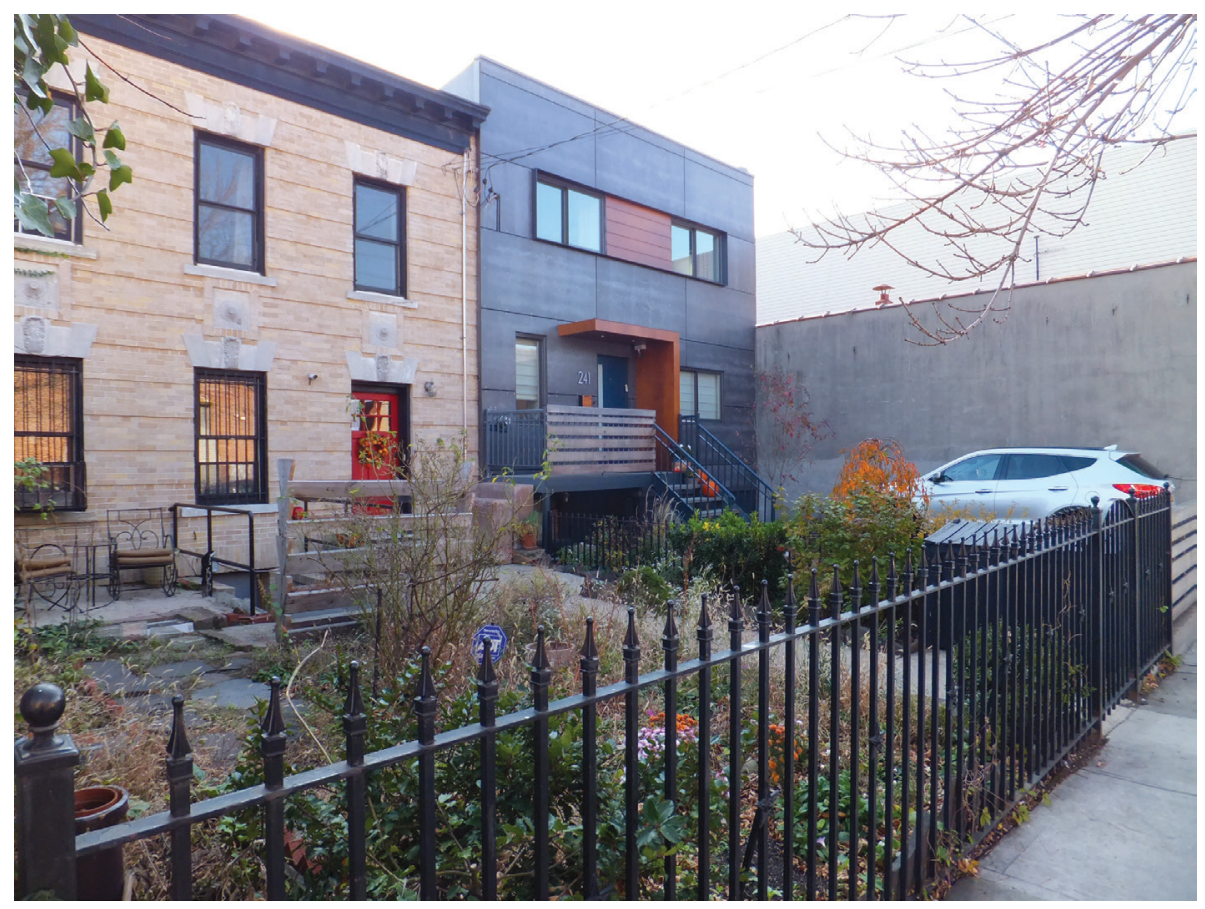

II. 8. Budynki mieszkalne jednorodzinne po przebudowie (fot. J. Huebner) III. 8. Single-family residential buildings after reconstruction 


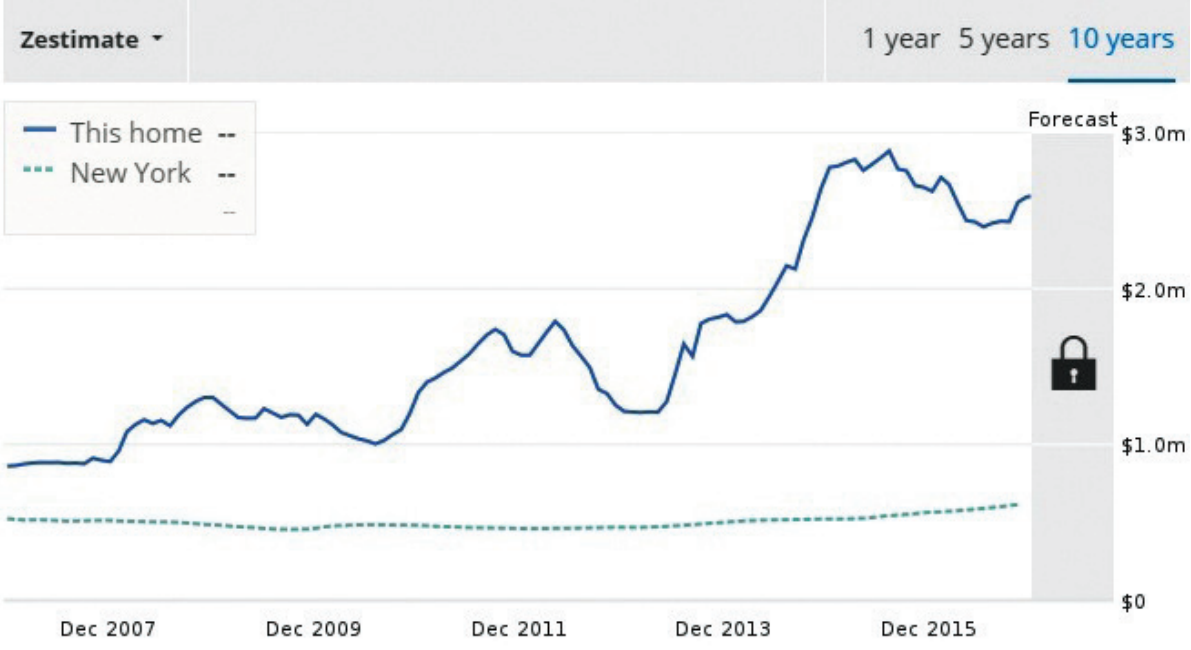

II. 9. Wzrost cen nieruchomości przy przy Sullivan St. (źródło: www.zillow.com) III. 9. Rise in property prices at Sullivan St.

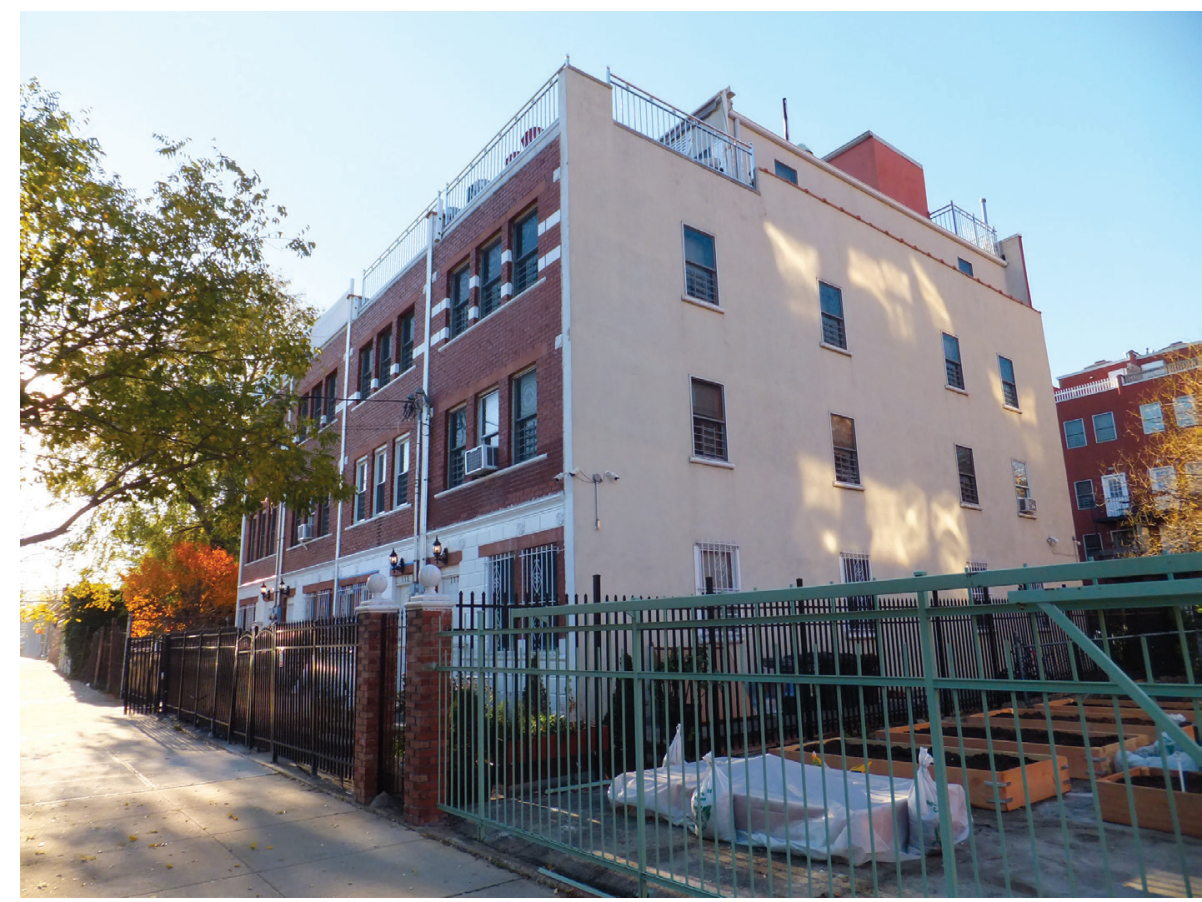

II. 10. Budynek mieszkalny wielorodzinny przy Sullivan St. (fot. J. Huebner) III. 10. Multifamily residential building at Sullivan St. 


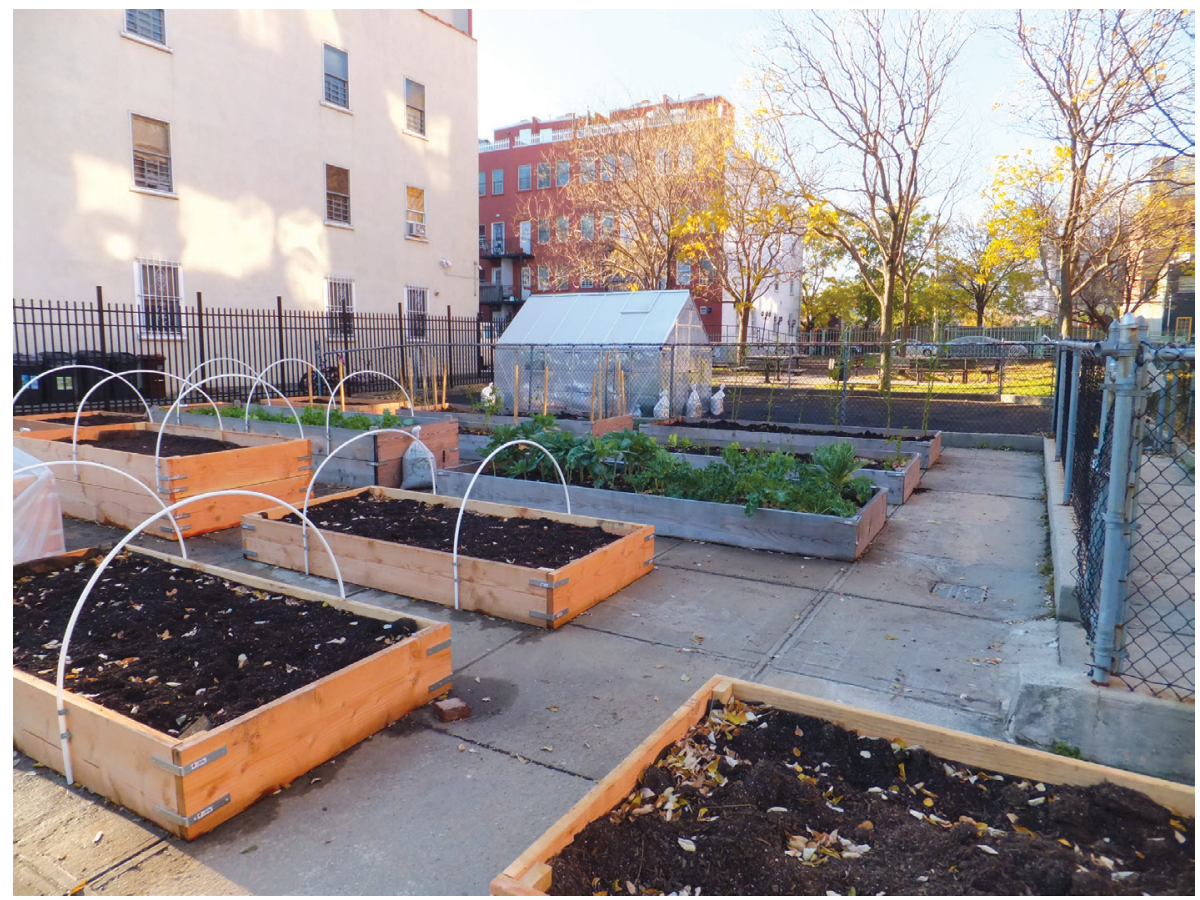

II. 11. Warzywniki przy Sullivan St. (fot. J. Huebner)

III. 11. Vegetable gardens at Sullivan St.

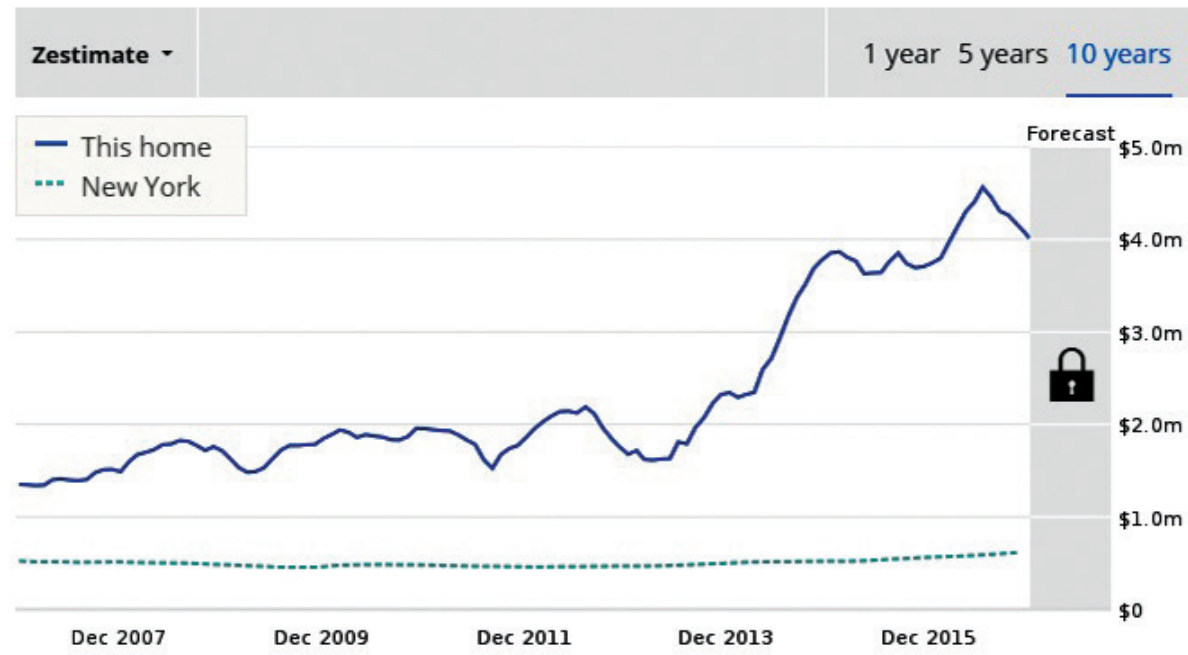

II. 12. Wzrost cen nieruchomości przy przy Van Brunt St. 346 (źródło: www.zillow.com) III. 12. Rise in property prices at Van Brunt St. 


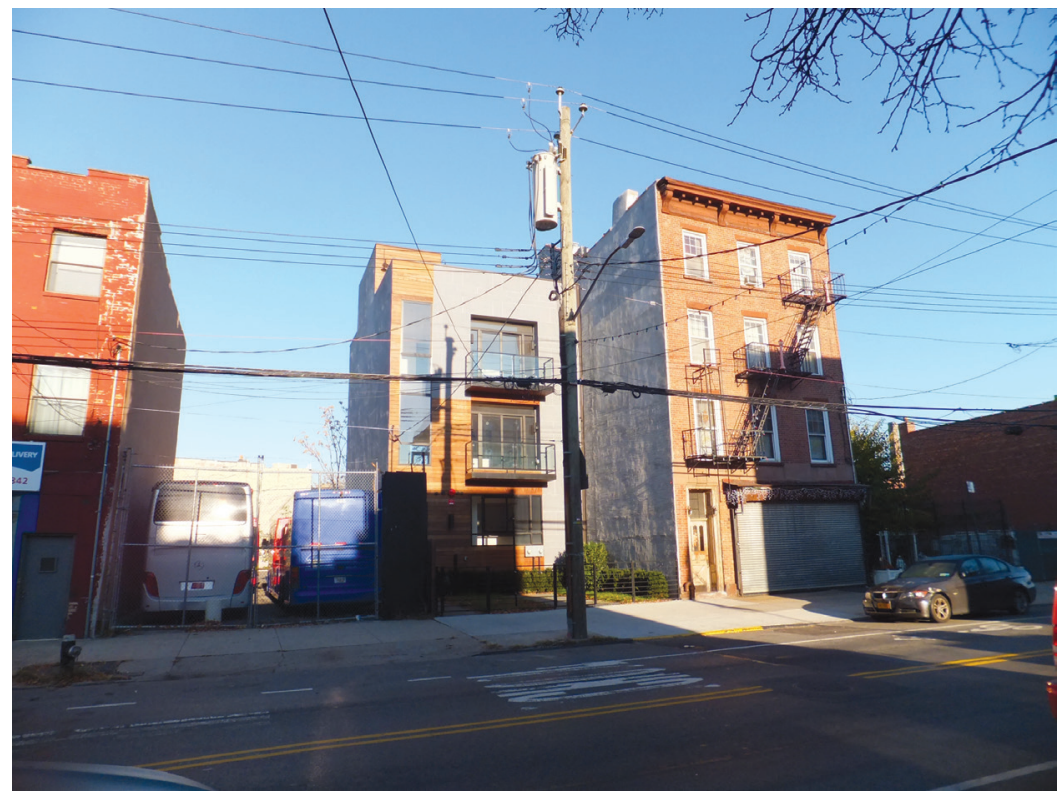

II. 13. Budynek mieszkalny wielorodzinny przy Sullivan St. (fot. J. Huebner) III. 13. Multifamily residential building at Sullivan St.

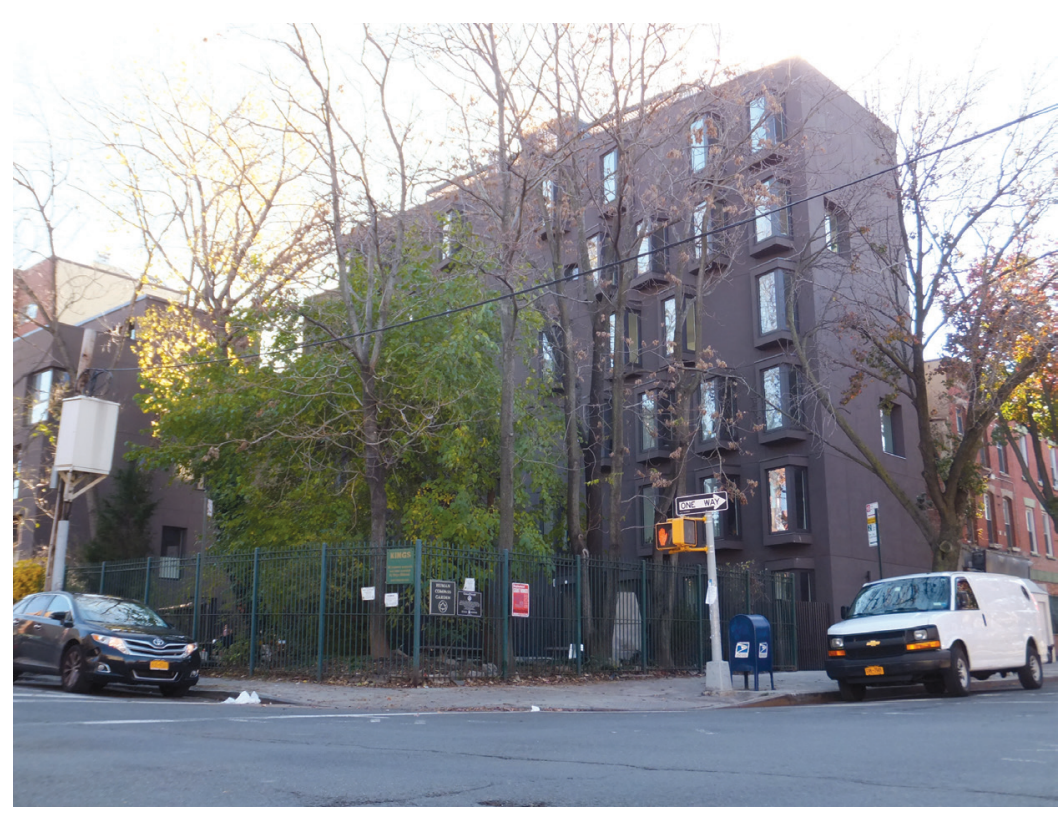

II. 14. Budynek mieszkalny wielorodzinny przy Sullivan St. (fot. J. Huebner) III. 14. Multifamily residential building at Sullivan St. 


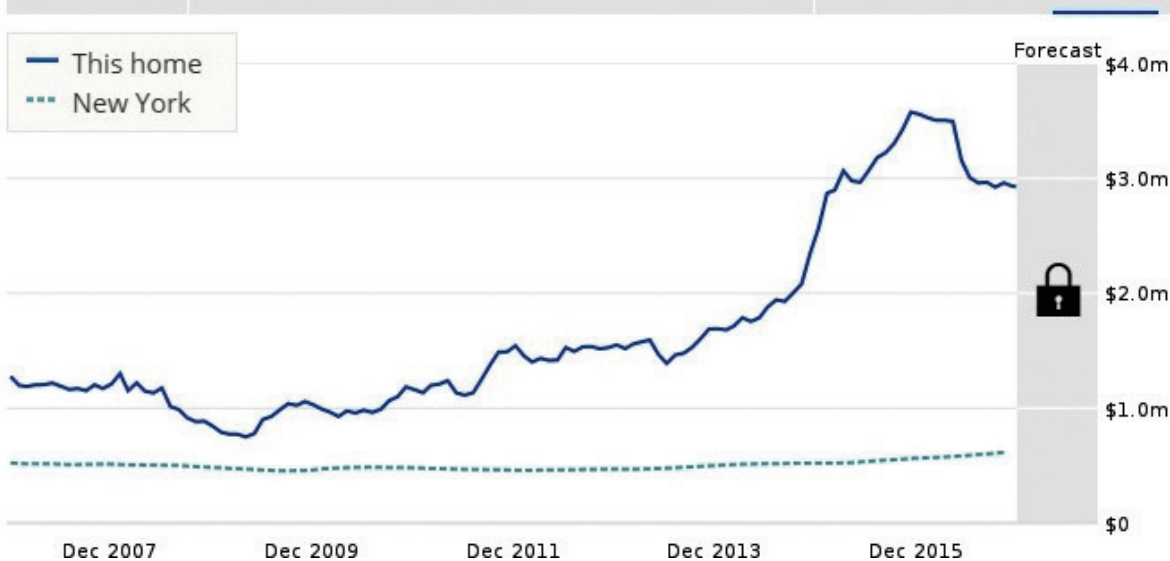

II. 15. Wzrost cen nieruchomości przy Columbia St. 65 (źródło: www.zillow.com) III. 15. Rise in property prices at Columbia St. 65

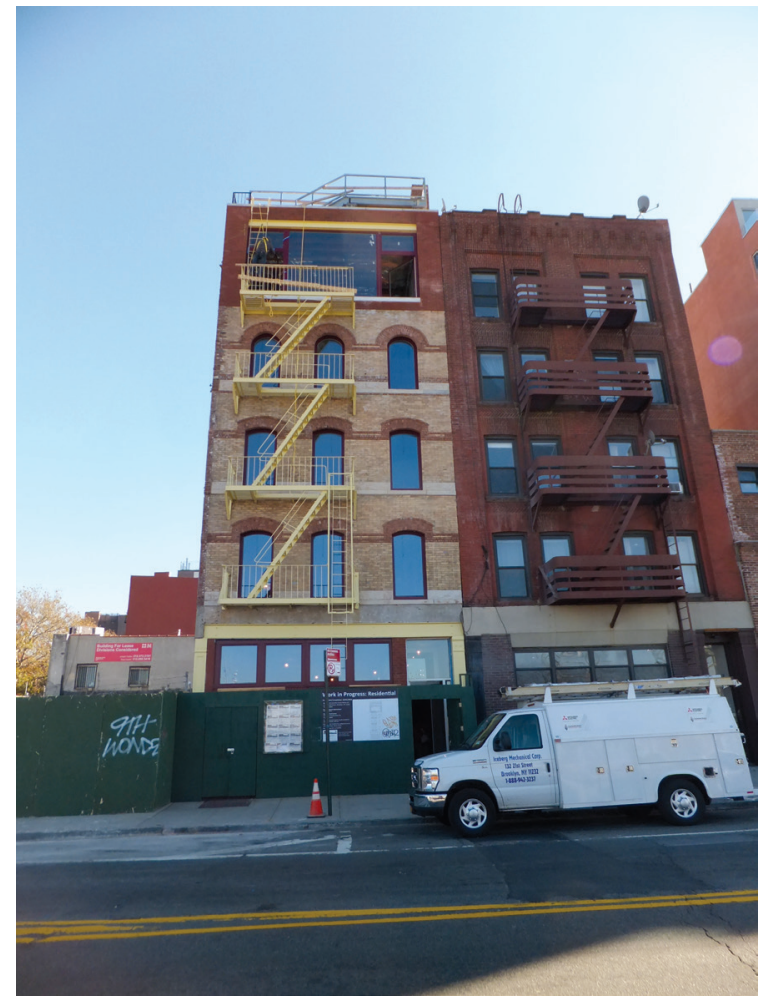

II. 16. Budynek mieszkalny wielorodzinny przy Columbia St. 65 (fot. J. Huebner) III. 16. Multifamily residential building at Columbia St. 65 


\section{Pierhouse at Brooklyn Bridge Park}

\section{Furman St, Brooklyn, NY 11201}

\section{For Sale 15 off Market}

\section{BEDROOM $\$ 2,900,000$}

2 BEDROOM $\$ 3,400,000-\$ 6,050,000$

3 BEDROOM $\$ 3,950,000-\$ 5,500,000$

4 BEDROOM $\$ 6,629,000-\$ 7,900,000$

5 BEDROOM $\$ 10,490,000$

II. 17. Wzrost cen nieruchomości przy przy Van Brunt St. 346 (źródło: www.zillow.com) III. 17. Rise in property prices at Van Brunt St. 346

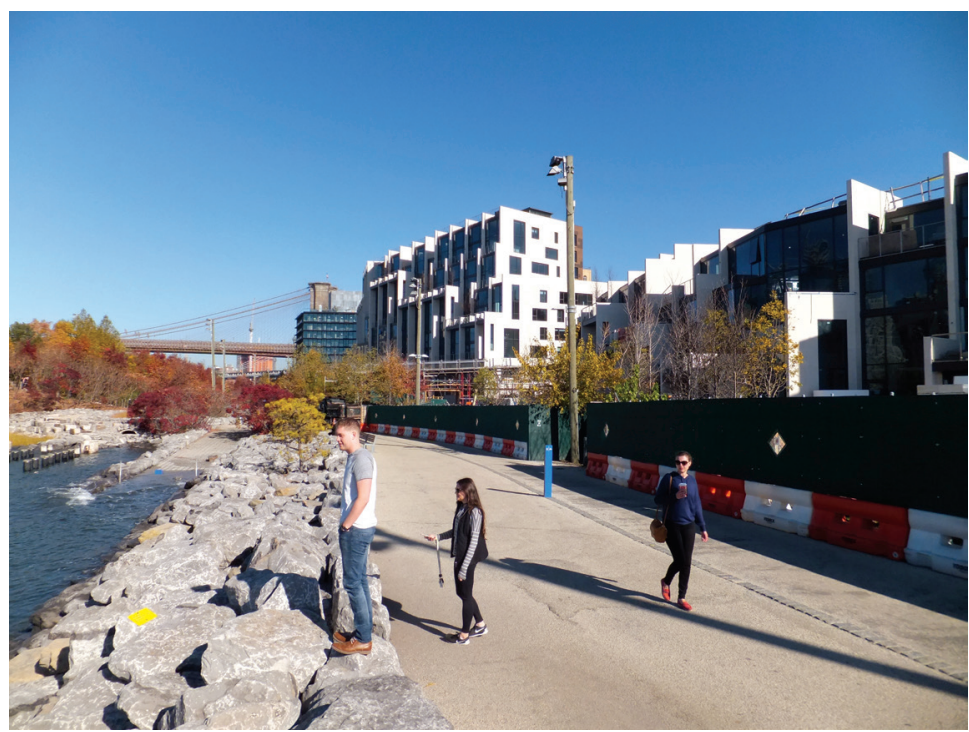

II. 18. Budynek mieszkalny wielorodzinny przy Furman St., widok od strony nabrzeża Brooklyn Bridge Park Greenway (fot. J. Huebner) III. 18. Multifamily residential building at Furman St.reet. View from the waterfront of Brooklyn Bridge Park Greenway 


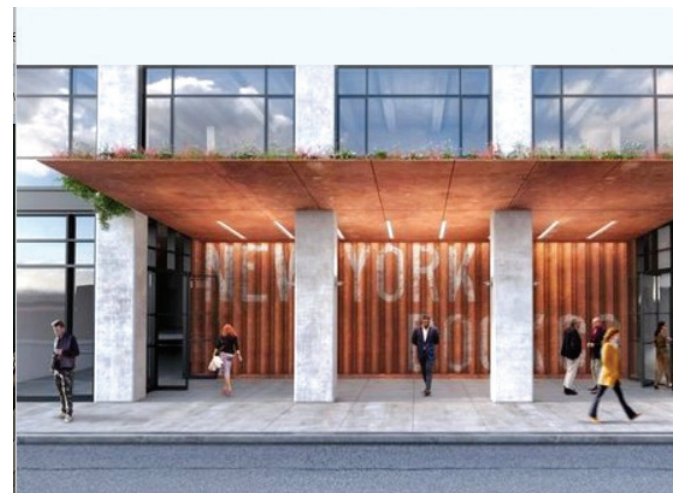

II. 19. Ceny apartamentów (źródło: www.zillow.com) III. 19. Prices of apartments
BUILDING

160 Imlay St

Brooklyn, NY 11231

52 units

1 BEDROOM $\$ 862,875-\$ 5,397,840$

2 BEDROOM $\$ 1,341,600-\$ 1,917,000$

\section{BEDROOM $\$ 2,217,775-\$ 3,613,500$}

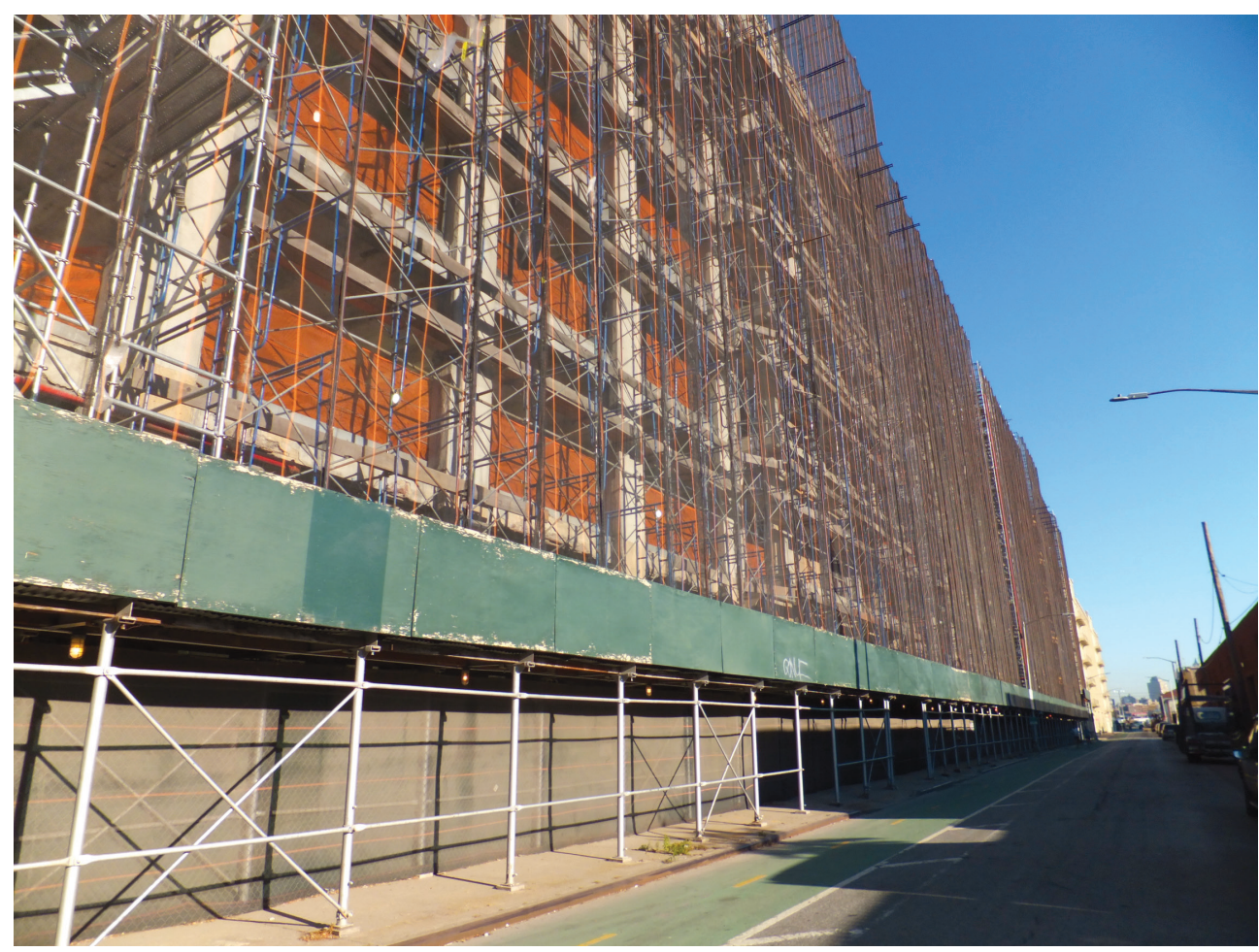

II. 20. Przebudowa dawnych budynków magazynowych przy Imlay St. 160 na mieszkania (fot. J. Huebner) III. 20. Reconstruction of former storage buildings at Imlay St. 160 per apartament 


\section{PRZYPISY}

1 R. Koolhaas, Deliryczny Nowy Jork, Wydawnictwo Karakter, Kraków 2013.

2 Nowy Jork, Wydawnictwo ExpressMap, Warszawa 2015.

3 Procesy gentryfikacji w mieście Tom I, J. Jakóbczyk-Gryszkiewicz (red.), Wydawnictwo Uniwersytetu Łódzkiego, Łódź 2012.

\section{BIBLIOGRAFIA}

Koolhaas R., Deliryczny Nowy Jork, Wydawnictwo Karakter, Kraków 2013.

Nowy Jork, Wydawnictwo ExpressMap, Warszawa 2015.

Procesy gentryfikacji w mieście Tom I, J. Jakóbczyk-Gryszkiewicz (red.), Wydawnictwo Uniwersytetu Łódzkiego, Łódź 2012.

www.zillow.com (dostęp: 11.2016).

www.neighborhoodscout.com (dostęp: 11.2016). 